A publication of the Muma College of Business | University of South Florida

\begin{tabular}{lll}
\hline Volume 4 & Number 12 & 31 DECEMBER 2019
\end{tabular}

ROBERT BERMUDEZ, JOSHUA KORLIN, DAMON MOORER, MARY SHAMMA, SANDI WALLACE

\title{
FRENEMIES IN BUSINESS: PARTNER OR COMPETITOR? ${ }^{1}$
}

\author{
"If one of our business partners unexpectedly becomes a competitor, how do we protect our \\ market share and continue to grow our business?"
}

\section{- Lynn Shaw, President and CEO, Dublin Payment Solutions}

As a new threat loomed in the distance, Lynn Shaw, President and CEO of Dublin Payment Solutions, knew she had to reevaluate her company's relationship with one prominent business partner. "Have you heard the latest news from Fintech Futures?" she asked her leadership team during a recent strategy session (see Exhibit 1). The question was rhetorical, and she quickly followed with a compelling statement, "U.S. Bank is preparing to sell Elan Financial Services, and Fiserv is favored to win the bid." The silence in the boardroom was unnerving as the implications of one of their largest competitors being acquired by a primary partner started to sink in.

Shaw fully understood that her clients relied heavily on Dublin to provide financial solutions aligned with digital experiences. Fiserv was one of her largest partners in the Financial Technology (fintech) industry; they also partnered heavily with fintech FIS. Both organizations provided payment processing platforms, electronic banking, mobile banking, application programming interfaces (APIs), loyalty platforms, and fraud detection neural networks. Eighty percent of Dublin's client base utilized one or more of these technologies.

Fiserv's acquisition of Elan Financial represented one of the most significant threats Dublin had encountered in its 30-year history. The notion of an adversary also being a friend was counterintuitive, but not uncommon in the payments industry. Payment and financial technology rivals often teamed up for mutual financial gain. If Fiserv acquired Elan Financial, how could Dublin mitigate the risk of a critical business partner becoming a competitor? As an aggregate provider of credit, debit, merchant, and accounts receivable solutions to over 3,000 financial institutions across the country, Dublin was wellknown in the financial sector for their quality, expertise, and experience. Was "coopetition" with Fiserv and Elan a viable option?

Shaw asked her team to create a multifaceted action plan to address this new threat. She wanted to know if Dublin could maintain a relationship with a partner who was also a competitor. Was there an opportunity to redesign the business model for mutual benefit? What was the best approach to ensure survival? Shaw knew her response to this threat would impact Dublin for years to come. Partner to frenemy in less than sixty seconds.

\footnotetext{
${ }^{1}$ Copyright (C 2019, Robert Bermudez, Joshua Korlin, Damon Moorer, Mary Shamma, Sandi Wallace. This case was prepared for the purpose of class discussion, and not to illustrate the effective or ineffective handling of an administrative situation. Some names and information have been disguised. This case is published under a Creative Commons BY-NC license. Permission is granted to copy and distribute this case for non-commercial purposes, in both printed and electronic formats.
} 


\section{The Payments Industry}

Payment for a good or service had existed since the beginning of time. However, the forms of payment and the manner in which those payments were exchanged had evolved continuously up to the present day (see Exhibit 2).

\section{History of Payment Methods}

Before the development of a medium of exchange (e.g., currency), people bartered to obtain the goods and services they needed. Two individuals, each possessing some good the other wanted, entered into an agreement to trade. (Beattie, 2018). However, this system was wildly inefficient unless two people had matching needs. In addition, trading goods complicated matters when two people couldn't agree that their goods were worth the same amount (e.g., a pig in exchange for a hammer).

Eventually coins and paper money emerged as a new form of payment. To keep their money safe, citizens turned to the temple. These places of worship and commerce were occupied by priests who were trusted to be honorable people. According to records, Greek, Roman, Egyptian, and Ancient Babylonian temples loaned money out, in addition to keeping it safe. (Beattie, 2018).

Around the 14th century, commercial banks unaffiliated with the state or temple emerged in Italy and throughout Europe. Julius Caesar, in one of his edicts that changed Roman law after his takeover, provided the first example of allowing bankers to confiscate land in lieu of loan payments. (Beattie, 2018). This set the precedent for modern-day banking.

The concept of consumer credit predated the concept of banking. According to scholars, the first consumer loans were issued in 3,500 B.C. in Sumer. As Dr. Stephen Bertman explained in The Handbook to Life in Ancient Mesopotamia (2005), they even had their own "credit cards" in the form of cylinder seals that were worn around the neck and served as a personal guarantee during business deals. If a Sumerian lost his cylinder seal, he recorded the date and time with an official to prove that transactions made with it after the loss were no longer valid. (Latham, 2018).

\section{Current Payment Methods}

While the world evolved, the financial system continued using coins and paper money as the primary form of payment. Each country had different types and values of money, but the monetary exchange principle remained the same. In addition to coins and paper money, new forms of payments have been created and adopted in the developed world. (Caldwell, 2018; "Payment method types").

- Check: Written instructions that directed a bank to issue funds to another party by subtracting that amount from the holder's account.

- Traveler's Check: A prepaid form of payment not linked to a bank account. Ideal to avoid carrying large sums of money.

- Money Order: Like a traveler's check, but with the restriction of smaller payment amounts.

- Debit Card: A plastic card tied to a bank account, which eliminated the need to carry checks.

- Credit Card: A plastic card issued by a bank that had determined risk tolerance for the consumer and extended a line of credit. The balance was paid every 30 days, or was subject to fees.

- Prepaid Card: A plastic card not tied to an account or line of credit. Instead the card was secured by a specific one-time payment. 
- Wire Transfer: When one bank issued money to another on behalf of a client.

- Direct Deposit \& Withdrawal: An automatic transaction issued by the account holder to pay or be paid from/to the debit account.

- Peer-to-Peer: A decentralized form of payment that allowed two individuals to exchange money without a bank acting as an intermediary. Examples included PayPal, Square Cash, and Venmo. (Rosenberg, 2018).

- Digital Currency: A form of payment that operated like physical currency in a digital medium. It allowed for instantaneous transactions and borderless transfer of ownership without fees. It was not supported by a central bank or government. Examples included Bitcoin, Ethereum, and Litecoin. (Bajpai, 2018).

With the evolution and adoption of financial technology, currency and forms of payment had drastically changed. Credit and debit card processing technology coupled with new mobile platforms made global financial transactions possible from any place at any time. Shaw's business strategy ensured Dublin clients had access to emerging payment technologies.

\section{The Banking Industry}

The banking industry included three for-profit market segments - national banks, regional banks, and community banks - as well as the non-profit credit union segment.

National and regional banks - collectively referred to as "large banks" - were generally defined as institutions with $\$ 1$ billion or more in total assets, though the top 100 banks in America had assets totaling between $\$ 8.8$ billion and $\$ 2.6$ trillion. (Badenhausen, 2018). They covered large geographic regions, if not the entire country. The largest of the US large banks were JPMorgan Chase \& Co., Wells Fargo \& Co., Bank of America Corp, and Citigroup Inc. (see Exhibit 3). (Dixon, 2018).

Community banks were generally defined as institutions with assets of $\$ 1$ billion or less. ("What is a community bank?", n.d.). By legal definition, community banks were locally owned and operated and not affiliated with a multibank holding company. ("Community Bank Law", n.d.).

Credit unions were non-profit financial institutions that were controlled by their members. Rather than generating profits for shareholders, credit unions returned their profits back to their members through products, services, and lower interest rates. (“Community bank vs.”, 2018).

\section{The Credit Industry}

The majority of large banks issued, underwrote, and guaranteed their own credit cards. In addition, they partnered with large businesses to collaborate on affinity cards. An example of this was JP Morgan's underwriting of the Amazon Credit Card. Alternately, to mitigate their risk, community banks and credit unions often partnered with providers such as Dublin for credit issuance programs. The largest credit program providers in this space were Elan, Dublin, Card Assets, TIB and First National Bank of Omaha.

There were several different revenue sources for credit card issuers, which made credit issuance an attractive, lucrative, and reliable business: (Sandberg, 2018). 
- Interest: More than 40 percent of cardholders carried a balance from month-to-month. Interest payments served as dependable income for issuers and accounted for the largest portion of their credit card revenue.

- Interchange Fees: Issuers charged merchants a fee to process each transaction, usually about 1.5 percent of the transaction amount.

- Cash Advance Fees: Issuers charged customers a fee to withdraw cash from the line of credit. Usually, the fee was 3 to 5 percent of the cash advance amount with a minimum fee of $\$ 5$ or $\$ 10$.

- Annual Fees: Some issuers charged cardholders a fee to maintain their account from year to year. This tactic was often used to lower the risk associated with customers with lower credit scores.

- Penalty Fees: If a payment was not received on time, the issuer generally charged the cardholder a late fee ranging from $\$ 10$ to $\$ 40$.

- Enhancements: Credit issuers also offered enhancements to credit cards such as insurance policies to protect the cardholder in the event of disability or unemployment.

- Other Fees: Issuers often chose to charge fees for other transactions, such as foreign exchanges and balance transfers.

The credit card industry was one of the largest consumer financial markets in the United States, and it was growing at a higher rate than the overall economy. According to industry research organization R.K. Hammer, credit card issuance revenue exceeded \$173 billion in 2017. (Hardekopf, 2017).

By 2017, credit card debt was at pre-recession levels. Credit card purchase volume exceeded previous highs. Emerging payment technologies and mobile payments provided people with more choices than ever. Credit card debt growth remained in lockstep with GDP indicating a healthy economic trend (see Exhibit 4). The majority of Americans had good credit, which reduced losses for financial institutions (see Exhibits $5 \& 6$ ). The average annual percentage rates on credit card accounts increased to a new high of $14.99 \%$, creating additional finance charge revenue. Credit cards remained the best option for consumers and business owners with good credit scores. (Latham, 2018).

\section{The Changing Landscape}

The credit industry created unprecedented revenue opportunities for financial institutions, processors, and payment companies. However, a few financial institutions felt the industry trends would not continue.

For example, despite the success of Elan Financial, U.S. Bank decided to sell that portion of their credit card assets at historically high premiums (O'Brien, 2016). In addition to receiving high cash infusions, Fifth Third Bank and U.S. Bank also reduced their unsecured lending exposure.

Shaw believed that these conditions enticed Fiserv and other nontraditional buyers to enter the credit issuance market, even though they had no direct experience in the credit issuer industry.

\section{Payment Processing Services}

In the simplest terms, the payment processor was the company that handled electronic transactions between two parties, such as a merchant and a customer. It accomplished the transaction by relaying the payment information, like a credit card, from the customer to the merchant's preferred bank account. If 
the account was valid and there were enough funds available, the transaction would be approved. This all occurred in a matter of seconds (Olenski, 2016).

\section{The Big Players}

The market for payment processing services was a growing segment led by three key players: FIS, Fiserv, and First Data Corp. These processing organizations led the industry in providing solutions for clients, allowing them to move money through a variety of instruments. They provided payment processing platforms, e-banking, m-banking, API reward platforms, and fraud detection neural networks.

FIS was headquartered in Jacksonville, Florida, and serviced over 20,000 clients in more than 130 countries. ("FIS Annual Report," 2018). Fiserv was headquartered in Brookville, Wisconsin, and serviced over 12,000 clients across 80 countries. ("About Fiserv"). First Data was headquartered in Atlanta, Georgia, and serviced over 4,000 clients in more than 100 countries. ("FDC 2017 Annual Report")

\section{The Process}

The volume of dollars that flowed through payment processing services each year numbered in the trillions. It was a lucrative business with a very positive outlook. In 2017, online payments increased by $28 \%$, Peer-to-Peer (P2P) payments increased by $32 \%$, and mobile payments by consumers increased by $67 \%$ versus prior year. ("FIS Annual Report," 2018). As the world became more digital and the expectation of instant gratification increased, the industry was poised to continue its upward trajectory.

Few consumers knew that these organizations existed, let alone what they did.

The payments processor is the financial institution that works in the background to securely process and complete a credit or debit card transaction. Payments processors typically charge a percentage of the transaction amount plus a flat fee for each debit or credit card purchase. ("Credit card processing fees").

On the surface, the credit card transaction process seemed simple: The customer inserted her card, and before she knew it, the transaction was complete. Behind every transaction, however, was a profoundly more complex procedure than what meets the eye. In fact, inserting the card and signing the receipt were only the first and final steps of a complicated procedure. The whole process - though it happened in just a few seconds - involved multiple stages and several actors working behind the scenes. Following are descriptions of the individuals and organizations involved. (Papadimitriou, 2009; Dwyer, n.d.).

- Cardholder: The consumer who purchased goods or services with a credit card.

- Merchant: The store/vendor who sold goods or services to the cardholder via credit card.

- Merchant Bank: The bank that received funds from the Merchant's sales.

- Credit Card Network: The entities that operated the networks that processed credit card payments worldwide, which included Visa, MasterCard, Discover, and American Express.

- Credit Card Issuer: The financial institution that issued the credit card involved in the transaction and provided funds for the Cardholder's purchases.

- Processor: The company that provided the services and devices that allowed the merchant to accept credit cards and send/receive credit card payment details. 
While the transaction seemed simple and took only seconds at the point of sale, the series of events that took place behind the scenes was a bit more complex:

1. The Cardholder presented the card to the merchant.

2. The Merchant processed the transaction.

3. The Merchant's Bank relayed the request for payment authorization to the Credit Card Network.

4. The Credit Card Network received the credit card payment details from the Merchant's Bank and forwarded the payment authorization request to the Credit Card Issuer.

5. The Credit Card Issuer sent a response back to the Credit Card Network approving (or declining) the transaction.

6. The Credit Card Network sent that response back to the Merchant's Bank.

7. The Merchant's Bank relayed that response back to the Merchant.

8. The Merchant completed the transaction.

9. The Cardholder signed the receipt and went on her way.

These steps were completed through devices and network gateways provided by the Processor. The processor acts as the mediator between the merchant and the financial institutions by managing the flow of requests and approvals through electronic devices. Exhibit 7 provides an illustration of the process.

\section{The Payoff}

In each of these transactions, a fee was generated as a percentage of the transaction value and/or a flat amount. The fees charged to merchants added up, so it was important for merchants to align with banks that would pool the number of transactions to drive down their processing service fees.

For example, for a $\$ 100$ transaction, the merchant may only have received $\$ 98$ after the transaction passed through all of the processing channels. Each entity may have charged a handling fee ranging from $\$ 0.15$ to $\$ 1.50$. While the numbers may not seem large for individual transactions, they added up to $\$ 4$ trillion in credit card transaction fees in 2014. (Heggestuen, 2014).

Annual revenues in 2017 were \$9 billion for FIS, \$5.7 billion for Fiserv, and \$7.4 billion for First Data. ("FIS Annual Report," 2018; “About Fiserv"; "FDC 2017 Annual Report”). With its purchase of Elan, Fiserv planned to increase revenue by entering the $\$ 173$ billion credit issuing industry.

\section{Dublin Payment Solutions}

Dublin Payment Solutions was founded in 1980 to give financial institutions access to comprehensive, affordable payment processing services to help maintain control of their customer relationships.

"Our mission is to deliver flexible, innovative payments and digital commerce solutions that allow smaller financial institutions to flourish."

- Lynn Shaw, President and CEO, Dublin Payment Solutions 
In 2017, Dublin served more than 2,000 community banks and credit unions, was the $24^{\text {th }}$ largest credit card issuer in the United States, and was the $10^{\text {th }}$ largest debit card issuer in the United States. Shaw shared that "service first and profitability second" was at the core of all they did. Part of their mission was to highlight the need to actively offer payment services in order to retain their best customers, earn profitable returns, and be respected as full-fledged participants in the marketplace.

Within the banking industry, Dublin operated within multiple verticals pertaining to payment solutions (see Exhibit 8) and was an exemplary payment provider, providing robust marketing, reporting, and consultative support - through the power of aggregation - to help institutions offer bank-branded credit and debit cards and merchant-acquiring services to consumers and small businesses.

\section{General Service Provider}

One of the roles that Dublin played was that of a General Service Provider (GSP). Payment processors like Fiserv and FIS used GSPs like Dublin to deliver processing services to financial institutions and local merchants. As a GSP, Dublin served as a gateway for these processors into small and midsize business markets. Partnering with a GSP reduced the processor's SG\&A (Selling, General, and Administrative) expenses, improving profit margins. Dublin was one of the largest and most successful GSPs in the industry.

\section{Credit Program}

In addition to providing processor services, Dublin also launched a credit card issuing program in 2001. The program provided professionally managed and fully branded credit products for 700 community banks and credit unions across the country, including consulting, portfolio acquisition, product development, and agent bank sponsorship options.

Historically, processing companies had steered away from offering credit issuing services, as that involved underwriting, risk management, and compliance expertise, which often fell outside of a processor's core competencies. However, in the case of Fiserv, it appeared that the revenue opportunity proved too lucrative to pass up.

\section{The Competition}

Elan Financial Services was Dublin's largest and most aggressive credit program competitor. A subsidiary of U.S. Bank, Elan provided credit programs to 1,400 financial institutions across the country. The two organizations competed directly to acquire new clients across the 48 contiguous states. The Elan and Dublin credit issuing programs were nearly identical. ("Grow your credit"; L. Shaw, personal communication, August 31, 2018). 


\section{Elan Financial Services}

- Consumer and Business products

- Visa, Mastercard, and American Express

- Rewards programs (e.g., cash back, miles)

- Fraud protection

- 24/7 customer service

- Online and mobile access

- \# of clients: 1,400

\section{Dublin Payment Solutions}

- Consumer and Business products

- Visa and Mastercard

- Rewards programs (e.g., cash back, miles)

- Fraud protection

- 24/7 customer service

- Online and mobile access

- \# of clients: 700

\section{Future Focus}

The long-term strategy for Dublin included building new solutions and pursuing acquisitions. With emerging technologies, the opportunity for acquisition had grown exponentially over the last five years.

"With the combination of banking and payments expertise along with proven solutions, Dublin is well positioned to pursue strategic acquisitions. Industry dynamics and financial institution demands have increased our need to innovate and expand our capabilities."

- Lynn Shaw, President and CEO, Dublin Payment Solutions

\section{Preparing for the Acquisition}

With the specific details of the acquisition still unknown, Shaw knew that she and her leadership team needed to start preparing for U.S. Bank's sale of Elan to Fiserv. While their initial discussions had focused on risks and threats to their business, within a couple of weeks, the overall tone of the conversation had changed significantly. Nearly everyone had started to look beyond the threats to the new opportunities that the acquisition would likely afford.

"There will be disruption and conversion when Elan is acquired. Customer disruption is a bad thing in a bank; as a result, banks rarely transition. That's where our opportunity would be. If they have to convert anyway, they might as well look at their options. We're working to position ourselves in the marketplace as a credible competitor and potential partner." - Lynn Shaw, President and CEO, Dublin Payment Solutions

\section{A New Engagement Model}

Shaw's leadership team realized there would be additional risk associated with Dublin's existing contract and working relationship with Fiserv upon their acquisition of Elan. A certain level of transparency would be required to continue operating the business. However, a new engagement model would have to be negotiated to protect their proprietary information from being divulged to Elan via Fiserv during the conversion period.

"We'll still have to tell them things we're doing while we run our business. Whatever we're doing, we'd have to have a good strategy mapped out to protect our proprietary data for 18-24 months. The risk is real, and it's not possible for us to get out any faster. We'll have to put rails in place to avoid divulging intellectual property."

$$
\text { - Aaron George, Chief Operating Officer, Dublin Payment Solutions }
$$




\section{The Long Divestment}

Dublin already worked with several processors, including Fiserv and First Data. Shaw knew that they would need to reduce their dependence on Fiserv due to the Elan acquisition. However, divestment didn't occur with the flip of a switch. Converting their existing Fiserv credit clients to another processor could take between 18 and 24 months. (A. George, personal communication, August 31, 2018). Dublin would need to deploy resources to shrink that window as much as possible.

\section{Room for Coopetition?}

Knowing that divestment would take 18-24 months, Shaw wondered whether coopetition with Fiserv and Elan might be possible - not only in the short-term, but also in the long-term. Contractual obligations and the realities of conversion would provide Dublin nearly two years to figure that out.

Cooperative competition, also known as coopetition, was the establishment of partnerships and strategic alliances with rival companies in an effort to create win-win scenarios for all parties involved. Multi-level success was the key objective as well as overcoming barriers with a united front. Cross-organizational capabilities commonly resulted in benefits that included, but were not limited to, cost reduction, knowledge sharing, efficient problem solving, and accelerated innovation. The complexity of a technology-integrated business landscape often required working together in an effort to increase customer and enterprise value. (Keane, 2017).

Examples of successful coopetition could be found across many industries:

- $\quad$ Samsung and Sony came together to jointly produce LCD screens. (Ihlwan, 2006).

- LinkedIn co-founder Reid Hoffman partnered and competed with headhunters. (Cabrera, 2014).

- Amazon brought third-party sellers into their own online store. (Palmquist, 2014).

- Toyota, Peugeot, and Citroen collaborated to design and produce a new car, and each company marketed the new model under different names with minor modifications. (Maziliauskaite, 2015).

Regardless of the potential value added from joining forces, limitations existed due to the overall risk and exposure of both enterprises. Preparation to defend against competitive compromise was critical. (Hamel, Doz, \& Prahalad, 1989). Firms were capable of breaching agreements, reneging on terms, and promoting self-serving interests to improve their competitive position independent of their partnership initiatives.

Dublin's credit issuance program was an exclusive offering that accounted for 40 percent of Dublin's total revenue. Dublin engaged in coopetition in order to leverage its current capabilities while gaining new proficiencies directly related to distinctive core competencies. The entrance of Fiserv into the credit issuance space threatened Dublin's overall profitability, but did that scenario also create a new coopetition model for Dublin to leverage?

\section{Adding New Fintech Partners}

One approach to reduce dependence on a partner was to establish a new B2B relationship. Dublin had looked at partnering with Vantiv (formerly Fifth Third) about two years earlier. Although Vantiv didn't have the technical capabilities that Dublin required at that time, Dublin was still impressed with the organization. (A. George, personal communication, August 31, 2018). They recently learned that Vantiv had since implemented the capabilities they needed, and Shaw looked forward to restarting conversations with them. 


\section{Buy vs. Build}

Another consideration for Dublin was whether to buy an existing Fintech firm or build their own payments hub. Either option would provide the opportunity to further reduce or even eliminate their dependence on outside partners. Within Shaw's leadership team, opinions varied on this topic.

"The whole building out of a payment solution is something that would give value-add back to clients. It makes sense. But I've been in the mode to buy. I think we've missed out on a couple of opportunities in the last dozen years."

- Kris Joseph, Executive Vice President Business Development, Dublin Payment Solutions

Proponents of buying an existing Fintech cited these reasons:

- Buying was faster than building.

- An existing fintech would have already had access to other outside systems (which would have had to be negotiated if Dublin built new). (L. Shaw, personal communication, August 31, 2018).

- Acquiring a small startup would have provided agility not possible with big payment processors.

Those in favor of building their own payment hub offered these perspectives:

- There were unique needs associated with Dublin's business model that would have been best addressed by a custom solution.

- Dublin would have had ultimate control over the functionality and development schedule.

\section{Core Competencies}

Whatever the decision, Shaw knew that they needed to rely upon and remain consistent with their core competencies. Dublin had a strong book of business and a large group of financial institutions that valued their payment solutions through Dublin's "Service First, Profitability Second" business model. Unlike Elan and Fiserv, Dublin's pricing models and objectives were materially different. This unique value proposition and core strength for delivering exemplary customer service provided a competitive opportunity for Dublin. Many in Shaw's leadership team believed that this acquisition would actually provide an opening for converting existing Elan customers over to Dublin.

While Fiserv was a leader in the financial technology space, the firm did not have expertise in running a credit program or managing a loan portfolio. (K. Joseph, personal communication, August 31, 2018). This was a core strength for Dublin that should be a key differentiator for them in the marketplace. However, it also made Shaw wonder if Elan's new parent company would try to poach any of her highly experienced leaders with lucrative job offers.

\section{The Decision}

The upcoming decision weighed heavily on Shaw's mind as the outcome would determine the future success and prosperity of Dublin. In the weeks that followed the Fintech Futures article, wide-ranging emotions were prevalent among her leadership team. Some feared that layoffs or a change of control disrupting current business initiatives were unavoidable. Others were insistent that the opportunity for growth from the inevitable change should be celebrated.

Shaw considered several options and the pros and cons of each. Despite the recent turmoil, she felt a great deal of confidence that Dublin would overcome this challenge and continue to thrive. The board of directors expected a well-defined strategy to address this new threat and her board meeting was on the 
horizon. Tasked with providing a formal set of recommendations, Shaw felt her usual pre-presentation jitters as she prepared. One of the following options would be presented to the board of directors:

- Commit to Coopetition - Continue doing business with Fiserv, while putting safeguards in place to protect proprietary information from making its way to Elan. This option required no significant change in strategy and allowed things to play out over time. Dublin would keep an eye on the market and rely on its market reputation, experience, and expertise going forward. Despite the best efforts of the Dublin team, however, coopetition could provide frenemy access to proprietary program information.

- End the Partnership - Start the process of divestment from Fiserv and identify a new fintech partner. Dublin would leave the relationship by the end of the current contract period, and a new partner would be offered an opportunity for new product development. This option would take 18-24 months to complete and would likely strain the relationship with Fiserv during the interim period. Service levels would inevitably wane, causing client loss estimated at $10 \%$.

- Acquire a Fintech (payments hub) - Dublin would acquire a payments fintech and divest from all fintech partners, including Fiserv, as contracts expired. A successful payments hub acquisition and conversion would reduce Dublin reliance on its business partners. The company would control solution development and deepen existing revenue streams. This move would open the door to new markets and diversification. Then again, overhauling a profitable business model was risky and would require a significant capital investment. Financial institutions are highly resistant to change. The disruption of an extensive conversion could cause a client exodus.

- Exit the Credit Issuing Business - Dublin could reallocate resources to other products and exit the credit issuing business altogether. Exiting the market would allow the current partnership with Fiserv to remain intact and unharmed. Dublin could focus on emerging technologies such as Peerto-Peer and Real Time Payment solutions. In addition, Dublin could offer credit consulting or portfolio management services. This option carried a significant downside as the credit issuing product line represented a key revenue driver for Dublin.

Dublin's business model had proven successful for more than 32 years. Despite the merger and acquisition activity in the financial sector, revenue had grown organically year after year. Business partners provided the technology foundation for the Dublin product suite, supporting the majority of the Dublin client base. Some leaders felt the time had come to restructure the business model and expand the service offering. Did Fiserv's acquisition of Elan create an unexpected opportunity to move forward or was it prudent to maintain the status quo? 


\section{References}

About Fiserv. (n.d.). Retrieved from https://www.fiserv.com/about.aspx

Badenhausen, K. (2018, January 10). Full list: Ranking America's 100 largest banks 2018. Retrieved from https://www.forbes.com/sites/kurtbadenhausen/2018/01/10/full-list-ranking-americas-100largest-banks-2018/\#540b37e23109

Bajpai, P. (2018, August 27). The 10 most important cryptocurrencies other than Bitcoin. Retrieved from https://www.investopedia.com/tech/most-important-cryptocurrencies-other-than-bitcoin/

Beattie, A. (2018). The evolution of banking over time. Retrieved from https://www.investopedia.com/articles/07/banking.asp

Bertman, S. (2005). Handbook to life in ancient Mesopotamia. Oxford University Press.

Cabrera, M. (2014, February 10). Use co-opetition to build new lines of revenue. Retrieved from https://hbr.org/2014/02/use-co-opetition-to-build-new-lines-of-revenue

Caldwell, M. (2018, May 6). The differences between money orders, bank checks, and cashier's checks. Retrieved from https://www.thebalance.com/money-orders-bank-checks-and-cashiers-checks2385803

Community bank law and legal definition. (n.d.). Retrieved from https://definitions.uslegal.com/c/community-bank/

Community bank vs. large bank vs. credit unions - the banking battle. (2018, May 09). Retrieved from https://smallbusinessapproval.com/community-bank/

Credit card processing fees and rates explained. (n.d.). Retrieved from https://squareup.com/guides/creditcard-processing-fees-and-rates

Dixon, A. (2018, February 21). America's 15 largest banks. Retrieved from https://www.bankrate.com/banking/americas-top-10-biggest-banks/\#slide=1

Dwyer, B. (n.d.). Credit card processing: How it works. Retrieved from https://www.cardfellow.com/blog/how-credit-card-processing-works/

FDC 2017 Annual Report. (n.d.). Retrieved from https://www.proxydocs.com/branding/964742/2018/ar/

FIS Annual Report 2017. (2018, February 22). Retrieved from https://www.fisglobal.com/about-us//media/fisglobal/files/report/2017-fis-annual-report.pdf

Grow your credit card business with minimal risk. (n.d.). Retrieved from https://www.elanfinancialservices.com/credit-card/program-support.html

Hamel, G., Doz, Y \& Prahalad, C.K. (1989). Collaborate with your competitors - and win. Harvard Business Review. Retrieved from https://hbr.org/1989/01/collaborate-with-your-competitors-and$\underline{\text { win }}$ 
Hardekopf, B. (2017, April 14). This week in credit card news: Many consumers don't redeem rewards; How profitable are card issuers? Retrieved from https://www.forbes.com/sites/billhardekopf/2017/04/14/this-week-in-credit-card-news-manyconsumers-dont-redeem-rewards-how-profitable-are-card-issuers/\#643c11437b51

Heggestuen, J. (2014). These are the main players in the credit card payments industry -- and who's most vulnerable to disruption. Retrieved from https://www.businessinsider.com.au/credit-cardindustry-disruption-2-2014-3

Ihlwan, M. (2006, November 28). Samsung and Sony's win-win LCD venture. Retrieved from https://www.bloomberg.com/news/articles/2006-11-28/samsung-and-sonys-win-win-lcdventurebusinessweek-business-news-stock-market-and-financial-advice

Keane, R. (2017, December 18). Driving business success through coopetition and specialization. Retrieved from https://www.piworld.com/article/driving-business-success-coopetitionspecialization/

Latham, A. (2018, April 3). 2018 consumer credit card industry study. Retrieved from https://www.supermoney.com/2018/04/credit-card-industry-report/

Maziliauskaite, K. (2015, January 19). Supply chain co-opetition: All for one, and one for all? Retrieved from https://www.allthingssupplychain.com/supply-chain-co-opetition-one-one/

O’Brien, J. (2016, August 11). Bank sells 'agent bank' credit card portfolio. Retrieved from https://www.grbj.com/articles/85902-bank-sells-agent-bank-credit-card-portfolio

Olenski, S. (2016, May 26). Top 10 payment processing companies in the world. Retrieved from https://marketingland.com/top-10-payment-processing-companies-world-175913

Palmquist, M. (2014, June 2). The Amazon model: If you can't beat 'em, work with 'em. Retrieved from https://www.strategy-business.com/blog/The-Amazon-Model-If-You-Cant-Beat-Em-Work-with$\underline{\text { Em?gko }=\mathrm{d} 33 \mathrm{~d} 3}$

Papadimitriou, O. (2009, April 2). How credit card transaction processing works: steps, fees \& participants. Retrieved from https://wallethub.com/edu/credit-card-transaction/25511

Payment method types. (n.d.). Retrieved from https://knowledgecenter.zuora.com/CB_Billing/L_Payment_Methods/Payment_Method_Types

Rosenberg, E. (2018, August 12). The 6 best payment apps to get in 2018. Retrieved from https://www.thebalance.com/best-payment-apps-4159058

Sandberg, E. (2018, November 15). How do credit card companies make money? Retrieved from https://creditcards.usnews.com/articles/how-do-credit-card-companies-make-money

What is a community bank? (n.d.). Retrieved from https://www.bankrate.com/glossary/c/communitybank/ 


\section{Biographies}

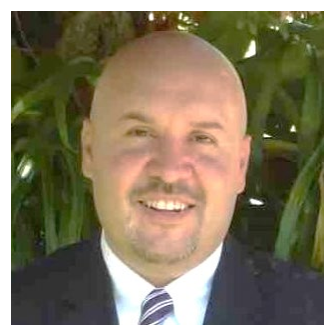

Robert Bermudez is Vice President HVAC East at MORSCO HVAC Supply. He received his undergraduate degree from The Ohio State University, and his Executive MBA from the University of South Florida.

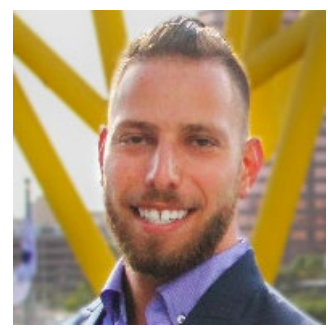

Joshua Korlin is the Sr. Manager of TBSE Partnership Development for the Tampa Bay Lightning. He was named in Tampa Bay Business Journal's 40 Under 40 list for 2018. Joshua received his undergraduate degree from Louisiana State University. He received his Executive MBA from the University of South Florida.

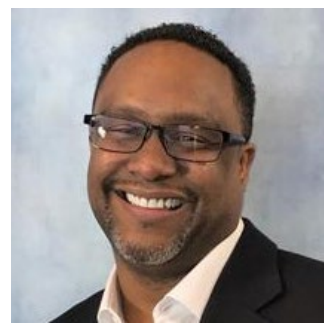

Damon Moorer is President and CEO of TCM Bank, N.A. Damon graduated from the University of Phoenix with a Bachelor of Science in Computer and Information Systems Security/Information Assurance. He is also a graduate of the Florida School of Banking, University of Florida. Damon received his Executive MBA from the University of South Florida.

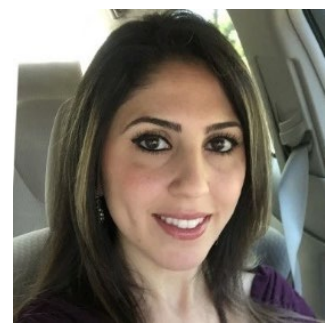

Mary Shamma is the Manager of Operations at Cornerstone Dental. She graduated from the University of South Florida with a Bachelor of Science in Finance. Mary received her Executive MBA from the University of South Florida.



Sandi Wallace is a Resource Manager at The Walt Disney Company where she serves as chief of staff to the Senior Vice President of Consumer Insight, Measurement \& Analytics. Sandi graduated with honors from Harding University with a Bachelor of Arts in Mass Communication. She received her Executive MBA from the University of South Florida. 


\section{Exhibit 1: Fintech Futures Article}

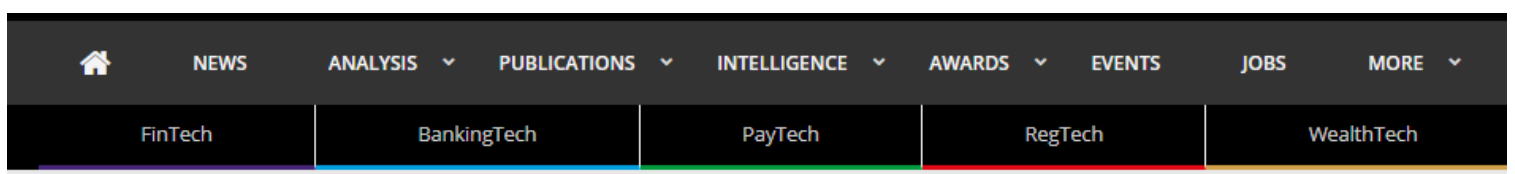

\section{FINTECH FUTURES}

News

\section{US Bank to sell card processor Elan}

Written by Antony Peyton 09 Aug 2018

EXCLUSIVE. US Bank is looking to offload its card processor business Elan, with Finastra, FIS and Fiserv believed to be in the final bid.



F-troop are moving in

Elan provides card processing services to $1,800+$ US banks. This includes payments services, credit card issuing, prepaid card solutions and ATM and debit card processing.

It also provides transaction processing, terminal driving and monitoring and support services for more than 34,000 ATMs across the US and supports more than 13 million ATM and debit cards.

Finastra, FIS and Fiserv have all been busy in paytech and bankingtech - and the deal would naturally strengthen their payments capabilities and deal a blow to any rival.

Back in June, Finastra acquired digital banking provider Malauzai to bolster its presence in the US retail and business banking sectors for credit unions and community banks. Finastra is of course the result of Misys and payments firm $\mathrm{D}+\mathrm{H}$ merging.

FIS hasn't been in a buying mood recently. But its payment capabilities are well known. Last year, US-based Fifth Third Bank chose FIS to enable real-time payments (RTP) for its customers through the Clearing House's (TCH) payments system.

For Fiserv, it made a big acquisition last year when it bought payments software vendor Dovetail.

FinTech Futures contacted US Bank, Elan, Finastra, FIS and Fiserv for comments.

Finastra, FIS and Fiserv offered a "no comment".

US Bank and Elan have not responded at the time of writing.

Source: Peyton, A. (2018). US Bank to sell card processor Elan. Retrieved 02/09/18 from

https://www.bankingtech.com/2018/08/us-bank-to-sell-card-processor-elan/ 


\section{Exhibit 2: A Brief History of Payment Methods}

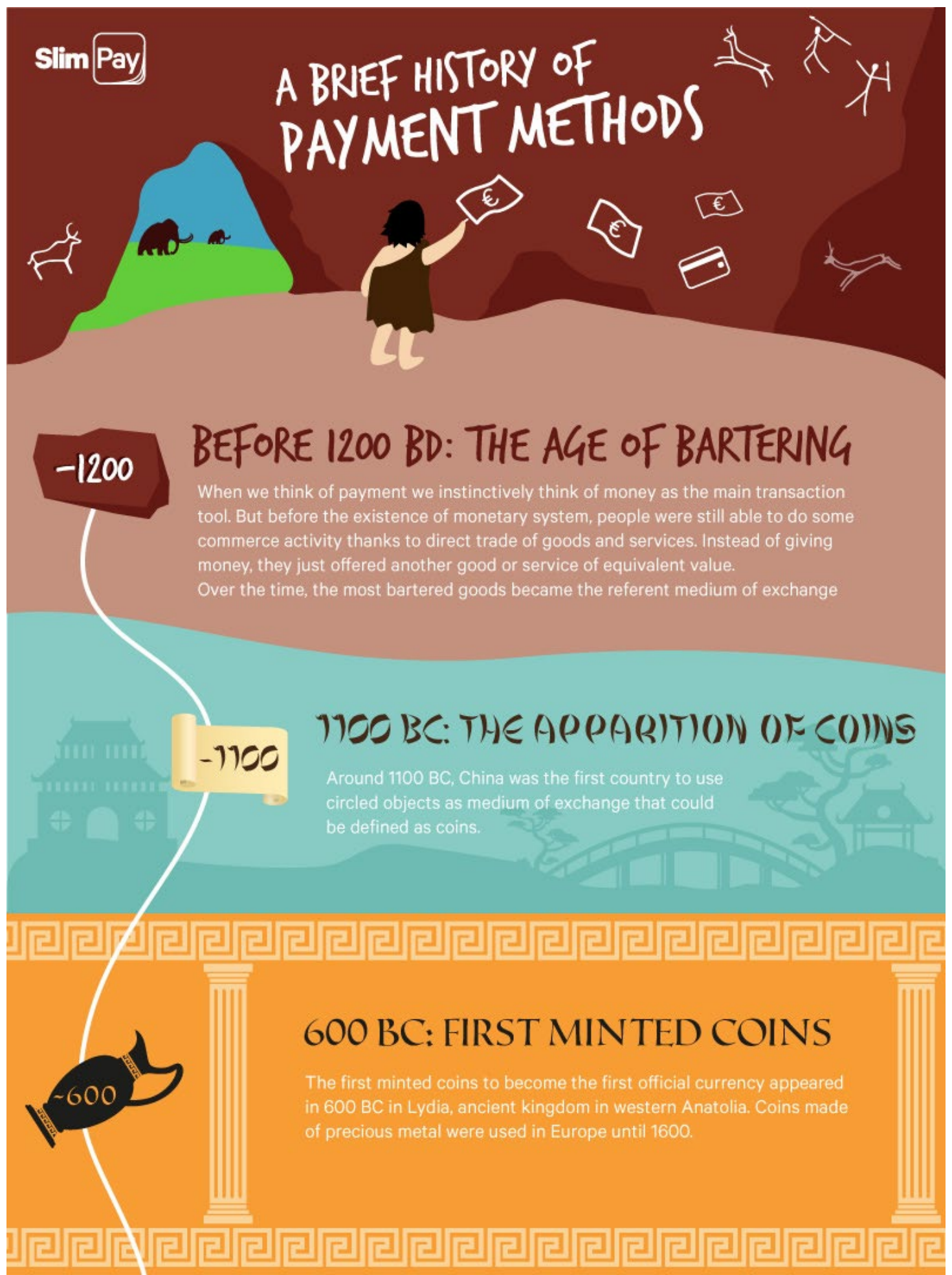




\section{Exhibit 2 (cont.): A Brief History of Payment Methods}

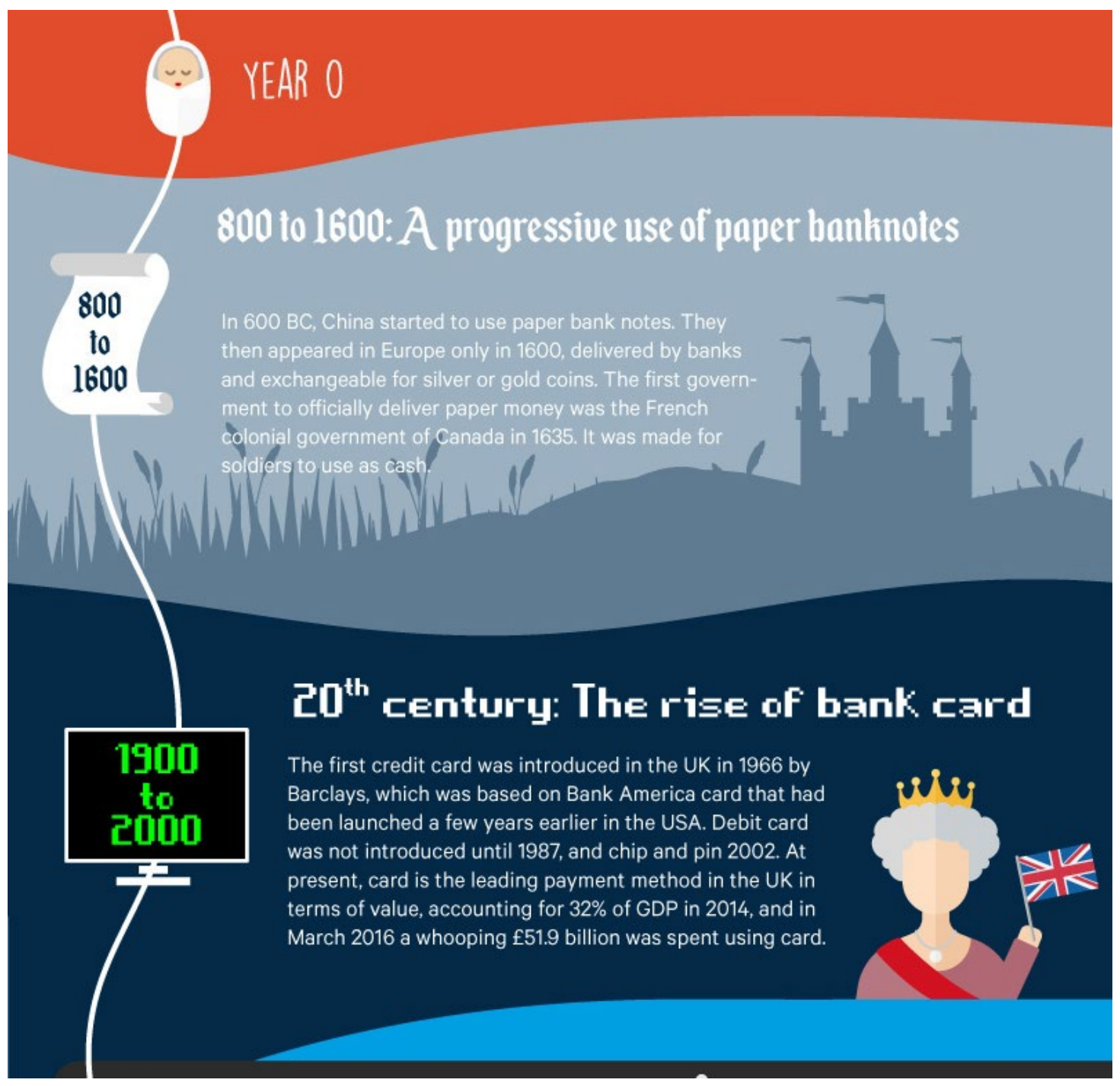




\section{Exhibit 2 (cont.): A Brief History of Payment Methods}

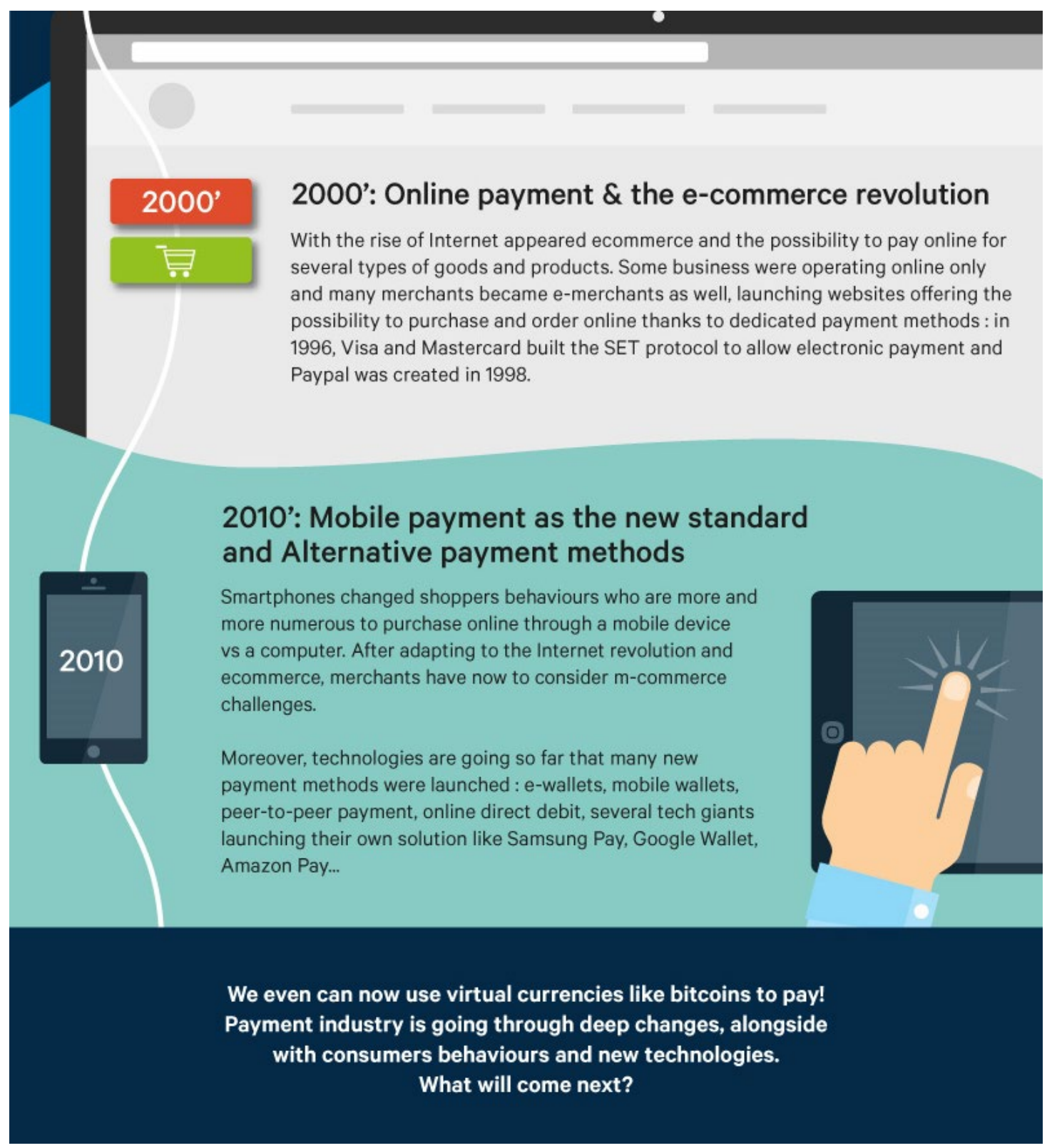

Source: INFOGRAPHIC: A Brief History of Payment Methods. (n.d.). SlimPay. Retrieved 15/09/18 from https://www.slimpay.com/blog/infographic-brief-history-payment-methods/ 


\section{Exhibit 3: Largest Banks in US}

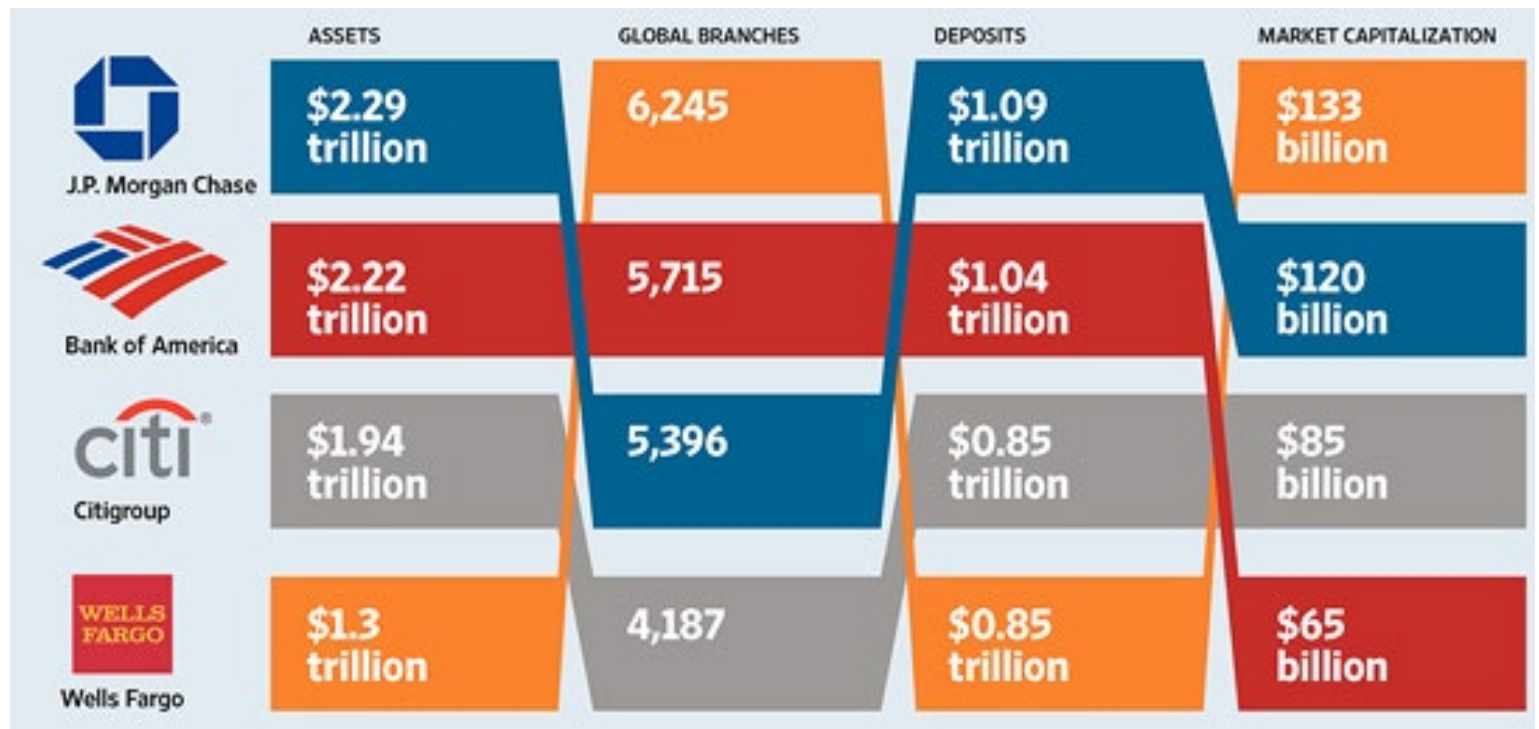

Source: Khan, H. (2017). Top 5 largest banks in US. Retrieved 04/09/18 from http://pkmediahub.com/top5-largest-banks-in-us/ 


\section{Exhibit 4: Credit Card Usage by GDP}

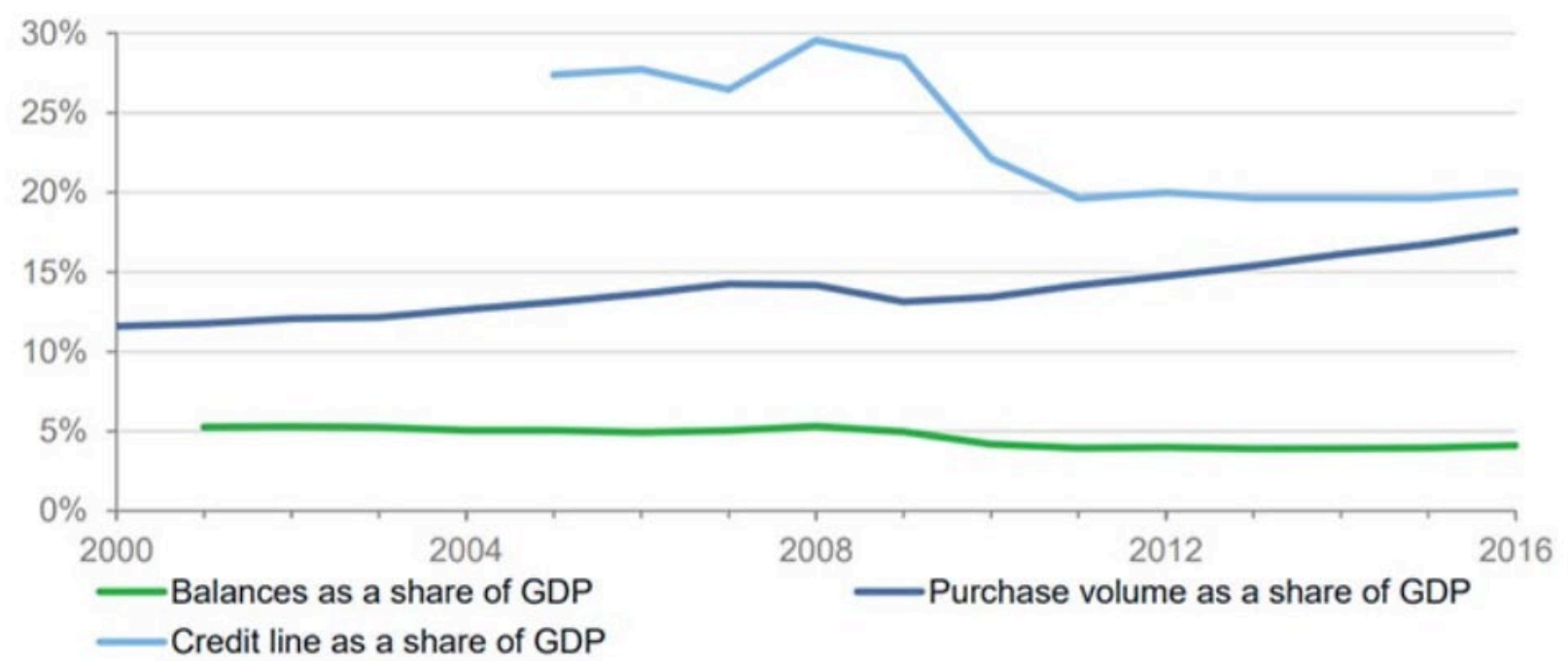

Source: The consumer credit card market. (2017, December). Retrieved 03/09/18 from https://files.consumerfinance.gov/f/documents/cfpb_consumer-credit-card-market-report_2017.pdf 


\section{Exhibit 5: The Majority of Americans Have Great Credit}

\begin{tabular}{ccc} 
& \multicolumn{2}{c}{ Credit Score Range Shares 2017} \\
Credit score tiers & $\begin{array}{c}\text { \% of U.S. population } \\
\text { with a credit score }\end{array}$ & $\begin{array}{c}\text { \% of U.S. scored credit } \\
\text { cardholding population }\end{array}$ \\
720 or greater & $56 \%$ & $62 \%$ \\
660 to 719 & $17 \%$ & $17 \%$ \\
620 to 659 & $9 \%$ & $9 \%$ \\
580 to 619 & $7 \%$ & $6 \%$ \\
579 or less & $11 \%$ & $6 \%$
\end{tabular}

Source: The consumer credit card market. (2017, December). Retrieved 03/09/18 from

https://files.consumerfinance.gov/f/documents/cfpb consumer-credit-card-market-report_2017.pdf 


\section{Exhibit 6: Delinquency and Charge-off Rates for Credit Cards}

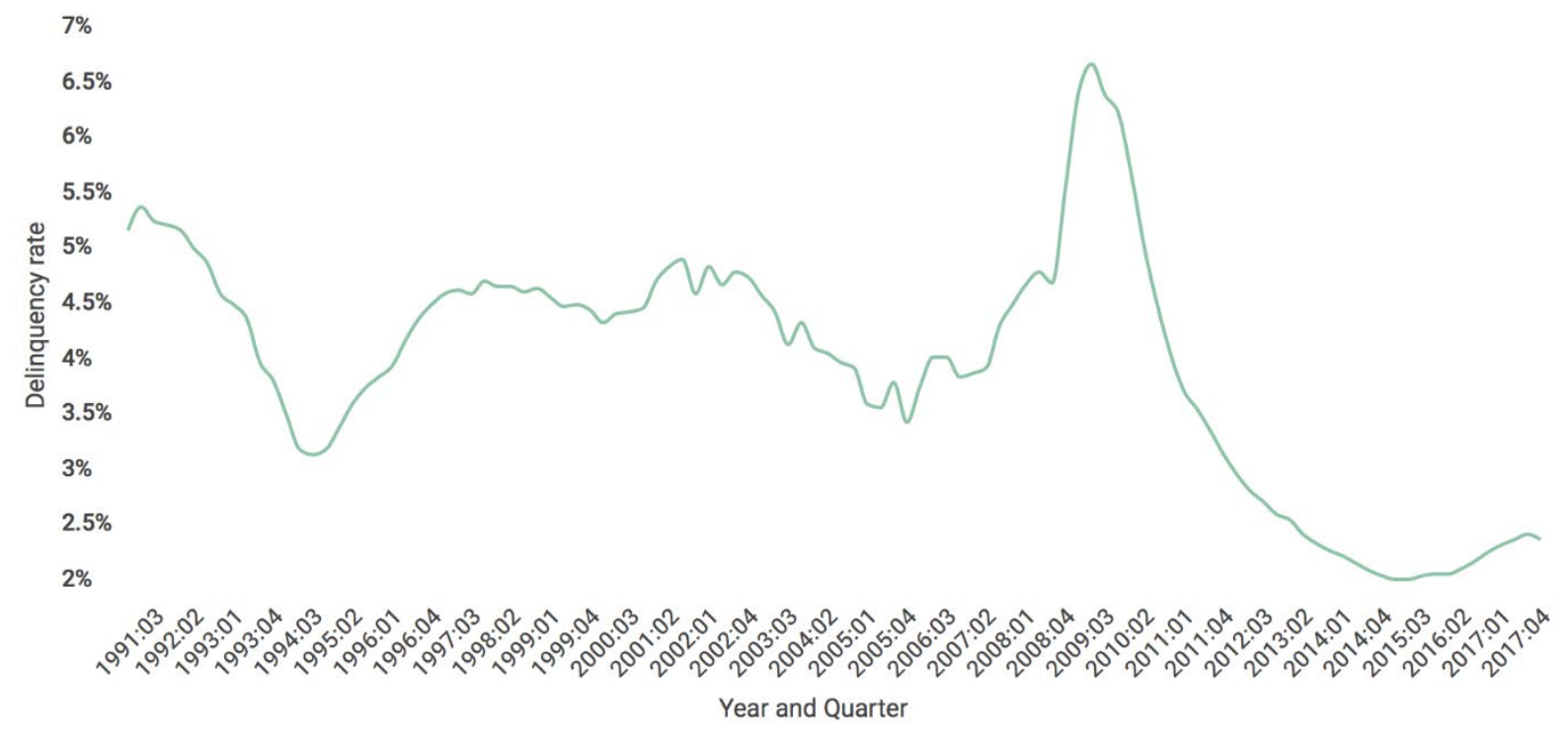

Source: The consumer credit card market. (2017, December). Retrieved 03/09/18 from

https://files.consumerfinance.gov/f/documents/cfpb_consumer-credit-card-market-report_2017.pdf 


\section{Exhibit 7: Credit Card Transaction Processing}



Source: Heggestuen, J. (2014). These are the main players in the credit card payments industry -- and who's most vulnerable to disruption. Retrieved 06/09/18 from https://www.businessinsider.com.au/creditcard-industry-disruption-2-2014-3 


\section{Exhibit 8: Dublin Product Lines}

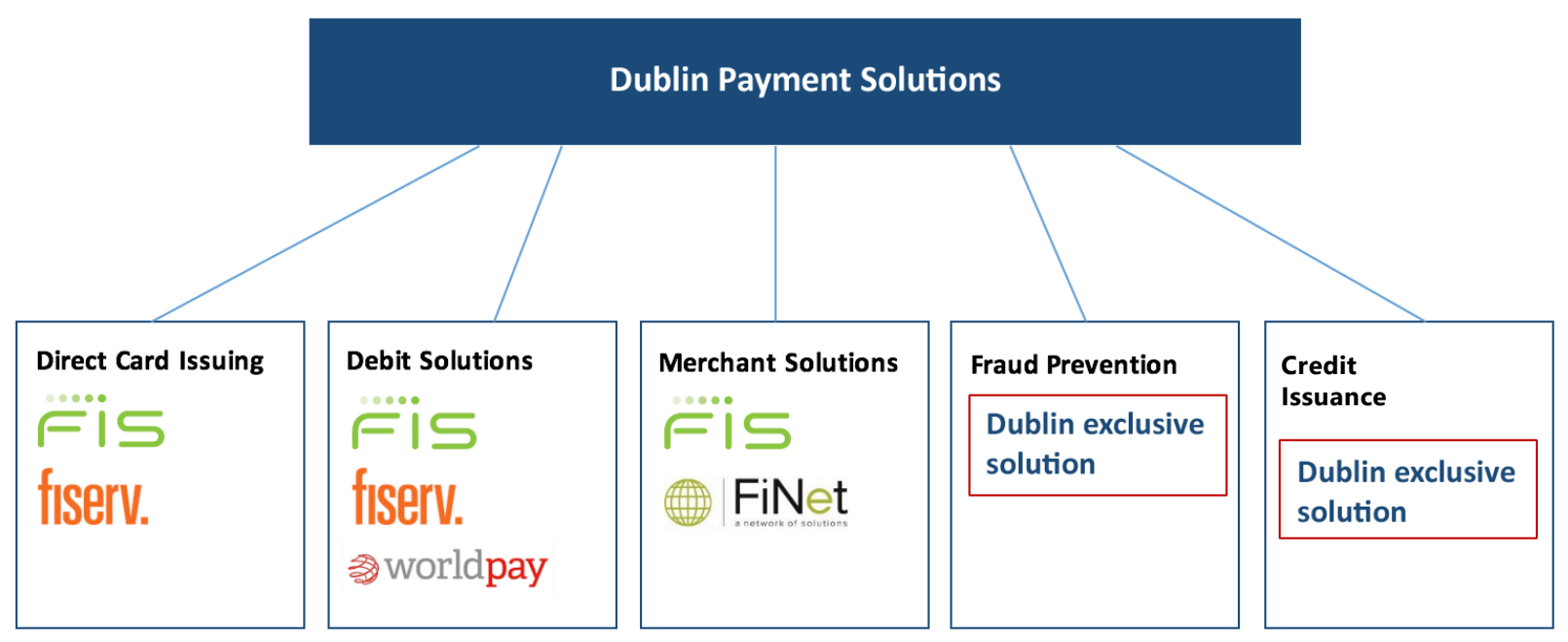

Source: Provided by Dublin Payment Solutions marketing team 17/09/18. 